\title{
Retreatment of Chronic Hepatitis C Infection with Telaprevir: Preliminary Results in Turkey
}

\author{
Bilgehan Aygen ${ }^{1}$, Orhan Yıldız ${ }^{1}$, Sıla Akhan ${ }^{2}$, Mustafa Kemal Çelen ${ }^{3}$, Onur Ural ${ }^{4}$, Süda Tekin Koruk ${ }^{5}$, \\ Şükran Köse ${ }^{6}$, Fatime Korkmaz ${ }^{7}$, Ziya Kuruüzüm ${ }^{8}$, Nazan Tuna ${ }^{9}$, Serpil Taheri ${ }^{10}$, Murat Sayan ${ }^{11}$, \\ Nazlım Aktuğ Demir ${ }^{4}$, Şua Sümer ${ }^{4}$, Elif Sargın Altınok ${ }^{2}$
}

\begin{abstract}
${ }^{1}$ Department of Infectious Diseases and Clinical Microbiology, Erciyes University Faculty of Medicine, Kayseri, Turkey ${ }^{2}$ Department of Infectious Diseases and Clinical Microbiology, Kocaeli University Faculty of Medicine, Kocaeli, Turkey ${ }^{3}$ Department of Infectious Diseases and Clinical Microbiology, Dicle University Faculty of Medicine, Diyarbakır, Turkey ${ }^{4}$ Department of Infectious Diseases and Clinical Microbiology, Selçuk University Faculty of Medicine, Konya, Turkey ${ }^{5}$ Department of Infectious Diseases and Clinical Microbiology, Harran University Faculty of Medicine, Şanluurfa, Turkey ${ }^{6}$ Department of Infectious Diseases and Clinical Microbiology, Tepecik Training and Research Hospital, İzmir, Turkey ${ }^{7}$ Department of Infectious Diseases and Clinical Microbiology, Konya Training and Research Hospital, Konya, Turkey ${ }^{8}$ Department of Infectious Diseases and Clinical Microbiology, Dokuz Eylül University Faculty of Medicine, İzmir Turkey ${ }^{9}$ Department of Infectious Diseases and Clinical Microbiology, Sakarya University Faculty of Medicine, Sakarya, Turkey ${ }^{10}$ Department of Medical Biology, Erciyes University Faculty of Medicine, Kayseri, Turkey

${ }^{11}$ Clinical Laboratory, PCR Unit, Kocaeli University Faculty of Medicine, Kocaeli, Turkey
\end{abstract}

Background: The use of pegylated interferon alpha and ribavirin (PegIFN/RBV) for the retreatment of chronic hepatitis $\mathrm{C}$ virus (HCV) infection without a sustained virological response (SVR) prior to PegIFN/RBV treatment has resulted in low success rates.

Aims: To investigate the efficacy and safety of telaprevir (TVR) in combination with PegIFN/RBV in patients infected with HCV genotypes 1 and 4 who were previously treated with PegIFN/RBV and failed to achieve SVR. Study Design: Multi-center, retrospective, cross-sectional study.

Methods: The study included 111 patients: 80 prior relapsers, 25 prior null responders, and six prior partial responders to PegIFN/RBV treatment. The patients were given TVR/PegIFN/RBV for 12 weeks, followed by a 12-week PegIFN/RBV treatment; virological response results were assessed at weeks 4,12 , and 24 . Treatment was discontinued in patients with HCV RNA $>1000$ IU/ $\mathrm{mL}$ at week 4 or with negative RNA results at week 4 but $>1000 \mathrm{IU} / \mathrm{mL}$ at week 12 . Rapid virological response (RVR), early virological response (EVR), extended rapid virological response (eRVR), and virological response at 24 th week of treatment were evaluated. The side effects of combination therapy and the rates of treatment discontinuation were investigated.
Results: The mean age of the patients was $56.02 \pm 9.96$ years and $45.9 \%$ were male. Ninety-one percent of the patients were infected with viral genotype $1,69.6 \%$ with the interleukin (IL) 28B genotype CT and $20.2 \%$ were cirrhotic. The RVR rate was $86.3 \%$ in prior relapsers, $56 \%$ in prior null responders, and $50 \%$ in prior partial responders $(\mathrm{p}=0.002)$. EVR rates in those groups were $91.3 \%, 56 \%$, and $83.3 \%$, respectively $(\mathrm{p}<0.001)$. eRVR rates were $83.8 \%$ in prior relapsers, $48 \%$ in prior null responders, and $50 \%$ in prior partial responders $(<0.001)$. The virological response at the 24th week of treatment was found to be the highest in prior relapsers $(88.8 \%)$; it was $56 \%$ in prior null responders and $66.7 \%$ in prior partial responders $(\mathrm{p}<0.001)$. Common side effects were fatigue, headache, anorexia, malaise, anemia, pruritus, dry skin, rash, dyspepsia, nausea, pyrexia, stomachache, and anorectal discomfort. All treatments were discontinued due to side effects in $9.9 \%$ of patients.

Conclusion: High virological response rates were obtained with TVR/PegIFN/RBV treatment. Although side effects were frequently observed, the discontinuation rate of combination therapy was low.

Keywords: Chronic hepatitis C, telaprevir, therapy, treatment-experienced.

This study was presented at the $24^{\text {th }}$ Annual Conference of Asian Pasific Association for the Study Liver, 12-15 March 2015, İstanbul, Turkey.

Address for Correspondence: Dr. Bilgehan Aygen, Department of Infectious Diseases and Clinical Microbiology, Medical School of Erciyes University, Kayseri,

Turkey Phone: +905362773671 e-mail: baygen@erciyes.edu.tr

Received: 16.05.2014 Accepted: 11.01.2015 • DOI: 10.5152/balkanmedj.2015.15366

Available at www.balkanmedicaljournal.org

Cite this article as:

Aygen B, Yıldız O, Akhan S, Çelen MK, Ural O, Koruk ST, et al. Retreatment of chronic hepatitis c infection with telaprevir: preliminary results in Turkey. Balkan Med J 2015;32:266-72. 
About 200 million people are known to be infected with the hepatitis $\mathrm{C}$ virus (HCV) worldwide (1). Chronic hepatitis C (CHC) infection carries risks of hepatic fibrosis, cirrhosis, portal hypertension, liver failure, and hepatocellular carcinoma $(2,3)$. Chronic HCV infection is an important health problem in Turkey, as it is around the world (4-6). The most frequently observed HCV genotype in Turkey is genotype $1 \mathrm{~b}$, with a rate of $68-94 \%$, but in recent years there has been an increase in genotype 4 infections $(7,8)$. Unfortunately, HCV treatment is difficult and the possibility of a sustained virological response (SVR) despite treatment is low in CHC associated with these genotypes. With 48 weeks of the administration of combination therapy using pegylated interferon alpha and ribavirin (PegIFN/RBV), the SVR rate is $40-50 \%$ in patients infected with HCV genotype 1 and $60 \%$ in patients infected with HCV genotype 4 (9-11).

Telaprevir (TVR) is a linear peptidomimetic HCV NS3/4A serine protease inhibitor. In previously conducted studies, the combination of TVR and PegIFN/RBV was shown to be successful in both treatment-naïve and treatment-experienced patients with chronic genotype $1 \mathrm{HCV}(12,13)$. It has been shown in three Phase 3 studies that TVR/PegIFN/RBV triplecombination therapy significantly increases SVR rates compared to double-combination therapy with PegIFN/RBV in treatment-naïve and treatment-experienced patients infected with genotype 1 who did not achieve SVR (14-16). In CHC patients infected with HCV genotype 4, triple-combination therapy with TVR had better results compared to double-combination therapy (17).

In this study, we aimed to evaluate the preliminary results of the combination therapy using TVR with PegIFN/RBV in $\mathrm{CHC}$ treatment in patients infected with genotypes 1 and 4 who previously received PegIFN/RBV treatment but failed to achieve SVR.

\section{MATERIALS AND METHODS}

\section{Patients}

This study included 111 patients (60 women, 51 men) who were followed up at seven university hospitals and two training hospitals between January 2013 and January 2014. The age range of the patients was 24-76 years, and the average age was $56.02 \pm 9.96$. In this retrospective study, closely monitored patients infected with HCV genotype 1 or HCV genotype 4 who had previously received at least $80 \%$ of the recommended PegIFN/RBV therapy but did not achieve SVR were evaluated. Patients with normal or high levels of liver enzymes, anti-HCV and HCV RNA positive, presenting with compensated disease with chronic hepatitis diagnosed by liver biopsy, ab- solute neutrophil counts $\geq 1200 / \mathrm{mm}^{3}$, platelet counts $\geq 90,000$ / $\mathrm{mm}^{3}$, and hemoglobin levels $\geq 12 \mathrm{gr} / \mathrm{dL}$ for women and $\geq 13 \mathrm{gr} /$ $\mathrm{dL}$ for men were included in the study (16). Patients with liver disease other than HCV infection, patients who were positive for anti-human immunodeficiency virus (anti-HIV), and patients with active cancer were excluded from the study. Liver biopsies were performed percutaneously and assessed according to the Ishak scoring system (18). In accordance with this system, scores of 0-2 were classified as "no or minimal fibrosis," 3 as "portal fibrosis," 4 as "bridging fibrosis, and 5-6 as "cirrhosis" $(14,16)$.

All of the subjects provided written informed consent for both treatment and genetic analysis. The study was approved by the Ethics Committee for Clinical Research at Kocaeli University, conforming to protocols in accordance with the Declaration of Helsinki (Decision number: 2013-37).

\section{Study design}

Patients were grouped according to their baseline viral load (HCV RNA $<800.000 \mathrm{IU} / \mathrm{mL}$ or $\geq 800.000 \mathrm{IU} / \mathrm{mL}$ ), viral genotype, interleukin (IL) 28B rs12979860 C/T polymorphism (CC, CT, or TT), stage of fibrosis, and type of prior response to PegIFN/RBV (null response, partial response, or relapse). Null response: a reduction of less than $2 \log 10$ in HCV RNA after 12 weeks of therapy. Partial response: a reduction of 2 $\log 10$ or more in HCV RNA after 12 weeks of therapy but with detectable HCV RNA. Relapse: undetectable HCV RNA at the end of a prior course of therapy, with HCV RNA positivity thereafter $(19,20)$.

Treatment to be administered and treatment duration were determined according to the National Health Application Notice of the Ministry of Health. In line with this notice, triple therapy combination with TVR is used in patients infected with HCV genotype 1 who have compensated liver disease and who have previously received PegIFN/RBV therapy but developed relapse. In patients with compensated liver disease, the total treatment duration is 48 weeks with 12 weeks of TVR therapy, provided that the liver biopsy Ishak score is stage $\geq 4$, the platelet count is below $100.000 / \mathrm{mm}^{3}$, or prothrombin time is over 3 seconds. In relapsed patients, total treatment duration is 24 weeks, including 12 weeks of TVR therapy if HCV RNA is negative at week 4 of treatment, and 48 weeks if HCV RNA is positive at week 4 of treatment. Treatment is discontinued if the HCV RNA value is found to be $>1000 \mathrm{IU} / \mathrm{mL}$ at week 4 or negative at week 4 but $>1000 \mathrm{IU} / \mathrm{mL}$ at week 12 .

The precirrhotic or cirrhotic or relapse patients meeting the abovementioned criteria of the Ministry of Health received treatment. For partial or null responder patients who agreed to receive treatment and those who did not meet the criteria, a special out-of-indication form and patient consent document 
were submitted to the Ministry of Health and approval was obtained. Thus, the patients could receive the treatment without any fee. Patients received TVR (Incivo; Janssen-Cilag SpA, Latina, Italy) orally at a dose of $750 \mathrm{mg}$ three times a day (every 8 hours) with food, PegIFN-2a (Pegasys; F. Hoffmann-La Roche Ltd Grenzacherstr, Basel, Switzerland) by the subcutaneous route at a dose of $180 \mu \mathrm{g}$ per week, and RBV (Copegus; F. Hoffmann-La Roche Ltd, Mississauga, Canada or Rebetol; Schering-Plough Products, Las Piedras, Puerto Rico) at a daily oral dose of $1000 \mathrm{mg}$ (patient weight $<75 \mathrm{~kg}$ ) or $1200 \mathrm{mg}$ (patient weight $\geq 75 \mathrm{~kg}$ ) or PegIFN-2b (Pegintron; ScheringPlough (Brinny) Company,Innishannon-County Cork, Ireland) by the subcutaneous route at a dose of $1.5 \mu \mathrm{g} / \mathrm{kg}$ per week and RBV daily oral dose of $800 \mathrm{mg}$ (patient weight $<65$ $\mathrm{kg}$ ), $1000 \mathrm{mg}$ (patient weight $65-85 \mathrm{~kg}$ ), $1200 \mathrm{mg}$ (patient weight $85-105 \mathrm{~kg}$ ), or $1400 \mathrm{mg}$ (patient weight $>105 \mathrm{~kg}$ ).

\section{Efficacy assessments}

Preliminary results of the first 24 weeks of treatment were evaluated. Quantitative HCV RNA was measured before the treatment and at weeks 4, 12, and 24. Responses obtained from patients during the 24 weeks of therapy were assessed according to the guidelines $(19,20)$.

\section{Safety assessments}

The patients were assessed clinically and the necessary biochemical, hematologic laboratory tests were performed at weeks 1,2 , and 4 of treatment and on a monthly basis thereafter. Side effects were recorded at each visit and necessary precautions were taken. Patients with serious side effects were controlled frequently; if necessary, they were hospitalized and/or triple therapy was discontinued.

In accordance with the RBV prospectus recommendations, doses were modified in patients who developed anemia. Erythrocyte transfusion was performed in patients whose anemia did not improve despite dose modification $(14,16)$. PegIFN dose reduction or discontinuation was done according to literature $(21,22)$.

Rash was scored as grade 1 (mild), grade 2 (moderate), or grade 3 (severe) $(14,16)$. For patients with grade 1 or 2 rash, medical intervention was provided. In patients with grade 2 rash that progressed or did not improve or with any grade 3 rash, all therapies were discontinued.

\section{Blood samples and laboratory tests}

Routine biochemical tests were performed on venous blood samples with an automated device and anti-HCV antibody examined using an enzyme immunoassay method (Architect System; Abbott Laboratories, Chicago, IL, USA). Quantitative HCV RNA measurement was performed using various real-time PCR quantification platforms and kits: 1) Qiasymphony/Rotor-Gene RG-Q, Artus HCV QS-RGQ (Qiagen, Hilden, Germany); 2) COBAS Ampliprep/COBAS TaqMan 48 (Roche Molecular Systems, Mannheim, Germany); and 3) Bosphore HCV Quantification v2 (Anatolia Geneworks, Istanbul, Turkey). The HCV genotype was determined using various laboratory techniques: 1) direct sequencing of the HCV NS3 region; 2) Inno-LiPA HCV II (Innogenetics, Ghent, Belgium); 3) AMPLIQUALITY HCV LIPA (AB Analitica, Padova, Italy); 4) real-time PCR (Abbott Molecular, Abbott Laboratories, Illinois, USA); and 5) PyroMark Q24 Pyrosequencing (Qiagen, Hilden, Germany). After DNA was isolated from blood samples, the samples were stored at $-80^{\circ} \mathrm{C}$. Genotyping for the IL-28B rs $12979860 \mathrm{C} / \mathrm{T}$ polymorphism was performed by a polymerase chain reaction-based restriction fragment length polymorphism assay (23).

\section{Statistical analysis}

The SPSS (SPSS, Inc., Chicago, IL, version 16.0) software package was used to perform the statistical analysis. The data are expressed as mean and standard deviation or as minimummaximum and median. Evaluation of the virological response was evaluated on an intention-to-treat basis by performing Pearson chi-square analysis. P-values less than 0.05 were considered statistically significant.

\section{RESULTS}

\section{Patients}

The demographic characteristics of the patients included in this study are shown in Table 1. Ninety-one percent of the patients were infected with HCV genotype 1 and $69.6 \%$ of the patients were IL28B genotype CT. Liver biopsies were performed in 84 patients, and $20.2 \%$ of the patients were cirrhotic. Compared to prior treatment responses, $72.1 \%$ of the patients were relapsers, $22.5 \%$ were null responders, and $5.4 \%$ were partial responders.

\section{Efficacy}

The patient responses included in the assessment are shown in Table 2. There were nine patients who failed to complete the first four weeks of treatment due to side effects. In all patients, RVR rate was $77.5 \%$, EVR rate was $82.9 \%$, eRVR rate was $73.9 \%$, and virological response rate at $24^{\text {th }}$ week of treatment was $80.2 \%$.

In five relapsers who failed to complete the first four weeks of treatment, virological response rates were not evaluated. HCV RNA was below $1000 \mathrm{IU} / \mathrm{mL}$ but positive in six of 80 
TABLE 1. Characteristics of 111 chronic hepatitis $C$ patients

\begin{tabular}{lc}
\hline Male sex - no. (\%) & $51(45.9)$ \\
Age in years ${ }^{\mathrm{a}}$ & $56.02 \pm 9.96$ \\
Alanine aminotransferase $-\mathrm{IU} / \mathrm{L}^{\mathrm{a}}$ & $57.20 \pm 41.03$ \\
HCV RNA log $10-\mathrm{IU} / \mathrm{mL}^{\mathrm{b}}$ & $6.00 \pm 0.07$ \\
$\quad \geq 800.000 \mathrm{IU} / \mathrm{mL}-$ no. $(\%)$ & $57(51.4)$ \\
HCV genotype $1-$ no. $(\%)$ & $101(91)$ \\
1a & $1(1.0)$ \\
1b & $84(83.2)$ \\
Subtype unknown & $16(15.8)$ \\
HCV genotype $4-$ no. $(\%)$ & $10(9)$ \\
IL28B rs12979860 C/T gene polymorphism - no. (\%) & \\
CC & $6(5.9)$ \\
CT & $71(69.6)$ \\
TT & $25(24.5)$ \\
Stage of fibrosis or cirrhosis - no. $(\%)^{\mathrm{d}}$ & \\
No or minimal fibrosis & $38(45.2)$ \\
Portal fibrosis & $14(16.7)$ \\
Bridging fibrosis & $15(17.9)$ \\
Cirrhosis & $17(20.2)$ \\
Prior type of response & \\
Relapse & $80(72.1)$ \\
Pull response & $25(22.5)$ \\
\hline
\end{tabular}

IL: interleukin

${ }^{\text {a Means }} \pm$ standard deviation

${ }^{b} \log 10$ values for HCV RNA are means \pm standard error

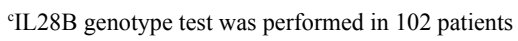

d84 patients with liver biopsy

TABLE 2. Treatment responses

\begin{tabular}{|c|c|c|c|c|}
\hline Patients & $\begin{array}{c}\text { RVR } \\
\text { n/total } \\
(\%)\end{array}$ & $\begin{array}{c}\text { EVR } \\
\text { n/total } \\
(\%)\end{array}$ & $\begin{array}{c}\text { eRVR } \\
\text { n/total } \\
(\%)\end{array}$ & $\begin{array}{c}24^{\text {th }} \text { week } \\
\text { of treatment } \\
\text { n/total }(\%)\end{array}$ \\
\hline Relapse $(n=80)$ & $69 / 80(86.3)$ & $73 / 80(91.3)$ & $67 / 80(83.8)$ & $71 / 80(88.8)$ \\
\hline $\begin{array}{l}\text { Null response } \\
(n=25)\end{array}$ & $14 / 25(56)$ & $14 / 25(56)$ & $12 / 25(48)$ & $14 / 25(56)$ \\
\hline $\begin{array}{l}\text { Partial response } \\
(\mathrm{n}=6)\end{array}$ & $3 / 6(50)$ & $5 / 6(83.3)$ & $3 / 6(50)$ & $4 / 6(66.7)$ \\
\hline $\mathrm{p}$ & 0.002 & $<0.001$ & $<0.001$ & $<0.001$ \\
\hline
\end{tabular}

relapsers at week 4. RVR was obtained in the remaining 69 patients. EVR, eEVR, and virological response at $24^{\text {th }}$ week of treatment could not be evaluated, as one of the patients was withdrawn from treatment for missing control visits after week 4 and another patient was withdrawn due to side effects. In relapsers, the eRVR rate and virological response rate at the $24^{\text {th }}$ week were higher compared to null responders and partial responders $(\mathrm{p}<0.001, \mathrm{p}<0.001)$. HCV RNA was negative in 66 of 67 patients with eRVR at week 24. In 71 patients with a virological response at the $24^{\text {th }}$ week of treatment, the parameters IL-28B genotype, viral genotype, baseline viral load, and stage of fibrosis were evaluated. IL-28B genotype was CT in 52, TT in 12 and CC in two. The IL-28B genotype test was not performed in five patients. Sixty-eight of the patients were infected with HCV genotype 1 and three were infected with HCV genotype 4. The HCV RNA level was below 800,000 $\mathrm{IU} / \mathrm{mL}$ in 43 of the cases. The fibrosis score was one in $31 \mathrm{pa}-$ tients, three in nine patients, five in nine patients, four in three patients, and six in two patients. Biopsies were not performed in 17 patients.

In three null responders and one partial responder who failed to complete the first four weeks of treatment, virological response rates were not evaluated. In 22 null responders, the RVR rate was $56 \%$. In six patients without RVR, triple therapy was discontinued due to HCV RNA levels above 1000 IU/ $\mathrm{mL}$. Five of these six patients were infected with HCV genotype 4 and one was infected with HCV genotype 1b. In the group of null responders, one patient was excluded from the assessment at week 9 due to side effects and another patient was excluded at week 10 due to a diagnosis of bladder cancer. The EVR and eRVR rates were $56 \%$ and $48 \%$, respectively, and the negativity rate at treatment week 24 was $56 \%$ in prior null responders. One of the six partial responders who did not achieve RVR achieved EVR. In this patient, the treatment was discontinued due to a virological breakthrough at treatment week 20 .

\section{Adverse events}

Side effects observed during treatment are shown in Table 3. Side effects detected in $25 \%$ of the patients included fatigue, headache, anorexia, malaise, anemia, pruritus, dry skin, rash, dyspeptic complaints, nausea, pyrexia, stomachache, and anorectal discomfort. Mild rash was observed in $66 \%$ of the patients.

The RBV dose was reduced in 57 patients $(51.4 \%)$ who developed anemia, and erythrocyte transfusion was performed in 36 patients $(32.4 \%)$. PegIFN therapy was discontinued for one to two weeks due to neutropenia in two patients, thrombocytopenia in two patients, systemic infection (complicated urinary system infection and viral upper respiratory tract infection) in two patients, and severe depression in one patient. The PegIFN dose was reduced due to thrombocytopenia in nine patients and neutropenia in four patients. All therapies were discontinued in 11 patients $(9.9 \%)$ due to side effects; the reason for discontinuation in $63.6 \%$ of these patients was gastrointestinal side effects (Table 3 ). 
TABLE 3. Adverse events during the overall treatment period

\begin{tabular}{|c|c|c|c|}
\hline Adverse events & no. $(\%)$ & Adverse events & no. $(\%)$ \\
\hline Fatigue & $90(81.1)$ & Psychiatric disorders & \\
\hline Headache & $87(78.4)$ & Depression $^{\mathrm{b}}$ & $25(22.5)$ \\
\hline Malaise & $79(71.2)$ & Anxiety & $12(10.8)$ \\
\hline Pyrexia & $29(26.1)$ & Insomnia & $9(8.1)$ \\
\hline Weight loss ${ }^{\mathrm{a}}$ & $17(15.3)$ & Mood impairment & $7(6.3)$ \\
\hline Cough & $14(12.6)$ & Emotional lability & $3(2.7)$ \\
\hline Gastrointestinal disorders & & Decrease in laboratory value & \\
\hline Anorexia & $87(78.4)$ & Hemoglobin ${ }^{c}$ & \\
\hline Dyspeptic complaints & $48(43.2)$ & To 8.5 to $\leq 10 \mathrm{~g} / \mathrm{dL}$ & $62(55.9)$ \\
\hline Nausea & $45(40.5)$ & To $<8.5 \mathrm{~g} / \mathrm{dL}$ & $27(24.3)$ \\
\hline Stomachache & $29(26.1)$ & Neutrophil & \\
\hline Diarrhea & $24(21.6)$ & To 500 to $<750 / \mathrm{mm}^{3 \mathrm{~d}}$ & $4(3.6)$ \\
\hline Vomiting & $21(18.9)$ & To $<500 / \mathrm{mm}^{3 \mathrm{e}}$ & $2(1.8)$ \\
\hline Dry mouth & $15(13.5)$ & Platelet count & \\
\hline Constipation & $16(14.4)$ & To 25.000 to $<50.000 \mathrm{~mm}^{3 \mathrm{~d}}$ & $9(8.1)$ \\
\hline Dysgeusia & $9(8.1)$ & To $<25.000 \mathrm{~mm}^{3 \mathrm{e}}$ & $2(1.8)$ \\
\hline Anorectal problems & & Other adverse events & \\
\hline Discomfort & $28(25.2)$ & Hypothyroidism ${ }^{\mathrm{f}}$ & $2(1.8)$ \\
\hline Hemorrhoid & $25(22.5)$ & Infection ${ }^{g}$ & $2(1.8)$ \\
\hline Pruritus & $23(20.7)$ & Reason for discontinuation & \\
\hline Hemorrhage & $17(15.3)$ & Anorectal problems & $3(2.7)$ \\
\hline \multicolumn{2}{|c|}{ Skin and subcutaneous tissue disorders } & Excessive nausea, vomiting & $3(2.7)$ \\
\hline Pruritus & $70(63.0)$ & Major depression & $1(1.8)$ \\
\hline Dry skin & $67(60.4)$ & Severe rash & $1(1.8)$ \\
\hline Rash & $53(47.7)$ & Upper gastrointestinal bleeding (Mallory-Weiss) & $1(1.8)$ \\
\hline Mild & $35(66.0)$ & Hemoptysis & $1(1.8)$ \\
\hline Moderate & $16(30.2)$ & Constitutional symptoms & $1(1.8)$ \\
\hline Severe & $1(1.8)$ & & \\
\hline
\end{tabular}

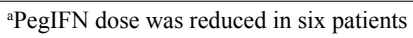

${ }^{b}$ Triple therapy was discontinued in one patient; PegIFN therapy was suspended in one patient for two weeks and antidepressant treatment was initiated and PegIFN treatment was continued thereafter.

${ }^{\mathrm{c}} \mathrm{RBV}$ dose was modified in $57(51.4 \%)$ patients and erythrocyte transfusion was performed in $36(32.4 \%)$ patients

${ }^{\mathrm{P}}$ egIFN dose was reduced

ePegIFN treatment was suspended for $1-2$ weeks

${ }^{\mathrm{f}}$ Autoantibodies were negative

gegIFN treatment was suspended for one week due to complicated urinary system infection in one patient and viral upper respiratory tract infection in one patient

\section{DISCUSSION}

When treatment-experienced $\mathrm{CHC}$ patients infected with genotype 1 have been retreated with TVR/PegIFN/RBV combination therapy, SVR rates have significantly increased $(13,16,24)$. The SVR rates obtained with triple therapy are different, depending on how patients respond to double therapy (relapse, partial response, or null response) $(13,16)$. In our study, the rates of RVR, eRVR, and virological response at the $24^{\text {th }}$ week of treatment were found to be higher in prior relapsers compared to prior null responders and prior partial responders. Although RVR and EVR rates were higher in prior null responders than in prior partial responders, the low number of prior partial responders might account for these results. The RVR rate was $86.3 \%$ in prior relapsers, $56 \%$ in prior null responders, and $50 \%$ in prior partial responders $(\mathrm{p}=0.02)$. In the randomized, double-blind, placebo-controlled, phase 3 study conducted by Zeuzem et al. (16), the PegIFN/RBV combination was compared to triple therapy with TVR in patients infected with the HCV genotype 1 who did not achieve SVR 
in prior treatments. RVR rates in the TVR/PegIFN/RBV group that did not receive lead-in treatment were found to be $70 \%$ in prior relapsers, $65 \%$ in prior partial responders, and $26 \%$ in prior null responders. SVR rates were higher in patients who achieved eRVR during treatment. In our study, the virological response rates at the $24^{\text {th }}$ week of treatment in all patients with eRVR were high in all patient groups. In a study conducted by Muir et al. (24), the impact of TVR combination therapy in treatment-experienced patients was evaluated; the overall SVR rate was found to be $59 \%$. SVR rates were $37 \%$ in prior null responders, $55 \%$ in prior partial responders, and $97 \%$ in prior relapsers.

HCV genotype 4 infection rates are high in the Middle East and Egypt, and its prevalence has begun to increase in southern European countries such as Italy, France, Greece, and Spain, depending on migration and changes in contamination modes of infection (17). In recent years, it has also been frequently observed in some geographical regions of Turkey (8). TVR is not an approved treatment option for patients infected with HCV genotype 4. In a phase 2a clinical study, TVR alone, PegIFN/RBV or a PegIFN/RBV/TVR combination was administered for two weeks in treatment-naïve patients infected with chronic genotype $4 \mathrm{HCV}$ infection (17). Antiviral activity was found to be higher in the triple-combination group compared to the other groups. In our study, a small number of patients $(9 \%)$ were infected with genotype 4 . In order to be able to discuss treatment success in these ten patients, SVR rates should be evaluated again later, and the results should be compared with those of the patients infected with HCV genotype 1.

In prior null responders or partial responders, cure is difficult when retreating patients with high pre-treatment HCV RNA levels and advanced stage liver fibrosis $(25,26)$. In a study conducted by Zeuzem et al. (16), although the basal HCV RNA level was high $(>800.000 \mathrm{IU} / \mathrm{mL})$ in $85 \%$ of patients, and the presence of cirrhosis was found in $26 \%$ of patients and bridging fibrosis in $22 \%$ of patients according to liver biopsy, the SVR rates in the TVR treatment arm were found to be higher in the combination group treated with PegIFN/RBV. In our study, the basal viral load was high in $51.4 \%$ of treated patients, and $38.1 \%$ had bridging fibrosis or cirrhosis. Since the number of patients was low when we evaluated the early treatment results, subgroup parameters affecting SVR were not analyzed. The IL28B rs $12979860 \mathrm{C} / \mathrm{T}$ polymorphism has been shown to play an important role in both double and triple therapies for CHC $(19,27)$. Although $94.1 \%$ of our cases had the CT or TT genotype, the virological response rate at the $24^{\text {th }}$ week of treatment was high.

In triple therapies with TVR, a rapid decrease in viral load in the early stage and high SVR rates are obtained. However, important side effects are observed. Pruritus, rash, anemia, and gastrointestinal side effects are most frequent. There is an $8-12 \%$ increase in treatment discontinuation due to side effects $(14,16)$. The most frequently observed side effects in our study were fatigue, headache, anorexia, malaise, anemia, pruritus, dry skin, rash, dyspeptic complaints, nausea, pyrexia, stomachache, and anorectal discomfort (Table 3). In 9.9\% of the patients, all therapies were discontinued due to side effects, which were mostly gastrointestinal. In a study conducted by Zeuzem et al. (16), side effects reported by more than $25 \%$ of the patients included fatigue, pruritus, rash, nausea, influenzalike illness, anemia, and diarrhea. Grade 3 side effects (mainly anemia, neutropenia, and leukopenia) were reported to be higher in the TVR treatment arms than in the control group. The prevalence of serious side effects was $12 \%$ and the rate of treatment discontinuation was $13 \%$.

In our study, rash rate was $47.7 \%$ and mostly mild in severity. In one patient (1.8\%), all therapies were discontinued due to severe rash. In previously conducted studies, the rates of rash and severe rash were reported as $37-43 \%$ and $5-6 \%$, respectively; TVR alone was discontinued in $7-11 \%$ of patients and all drugs were continued in $0.5-1.4 \%$ of patients due to rash $(14,16,24)$.

In addition, $80.2 \%$ of our patients developed anemia. The RBV dose was modified in $51.4 \%$ and erythrocyte transfusion was performed in $32.4 \%$ of the patients. Except for one patient who developed gastrointestinal bleeding and anemia, there was no indication of treatment discontinuation. The rate of treatment discontinuation due to anemia was reported to be low in previously conducted studies (14-16,24). In our study, as with other side effects, the rates of anemia and anorectal problems were found to be higher than those reported in the literature $(14-16,24)$. The treatment was discontinued due to anorectal problems in three patients $(2.7 \%)$.

This study shows that the virological response rate at the $24^{\text {th }}$ week of treatment was high with TVR/PegIFN/RBV combination therapy in patients infected with CHC genotypes 1 and 4 who failed to achieve viral eradication with prior PegIFN/RBV combination therapy. Although the rate of side effects with TVR observed in our study was higher compared with previous studies, the treatment discontinuation rate was not high.

Ethics Committee Approval: The study was approved by the Ethics Committee for Clinical Research at Kocaeli University, which conforms to protocols in accordance with the Declaration of Helsinki (Decision number: 2013-37).

\section{Informed Consent: N/A.}

Peer-review: Externally peer-reviewed.

Author contributions: Concept - B.A., O.Y.; Design - B.A., O.Y., S.A., M.K.C., O.U., S.T.K., S.K., F.K., Z.K., N.T.; Supervi- 
sion - B.A., O.Y.; Resource - B.A., O.Y.; Materials - B.A., O.Y., S.A., M.K.C., O.U., S.T.K., S.K., F.K., Z.K., N.T., S.T., M.S., N.A.D., S.S., E.S.A.; Data Collection \&/or Processing - B.A., O.Y.; Analysis \&/or Interpretation - B.A., O.Y.; Literature Search - B.A.; Writing - B.A., O.Y.; Critical Reviews - B.A., O.Y.

Acknowledgements: We thank Assistant Professor Gökmen Zararsiz (Department of Biostatistics, Medical School of Erciyes University, Kayseri, Turkey) for his statistics support.

Conflict of Interest: No conflict of interest was declared by the authors.

Financial Disclosure: The authors declared that this study has received no financial support.

\section{REFERENCES}

1. Hepatitis C. Geneva: World Health Organization, 2011. (http:// www.who.int/vaccine research/diseases/hepatitis_c/en/.)

2. World Health Organization. Global surveillance and control of hepatitis C: report of a WHO consultation organized in collaboration with the Viral Hepatitis Prevention Board, Antwerp, Belgium. J Viral Hepat 1999;6:35-47. [CrossRef]

3. Thomas MB, Jaffe D, Choti MM, Belghiti J, Curley S, Fong Y, et al. Hepatocellular carcinoma: consensus recommendations of the National Cancer Institute Trials Planning Meeting. J Clin Oncol 2010;28:3994-4005. [CrossRef]

4. Aygen B. Hepatitis C. Turkiye Klinikleri J Int Med Sci 2006;2:21-33.

5. Bozkurt I, Aygen B, Gökahmetoglu S, Yildiz O. Hepatitis C and occult hepatitis $\mathrm{C}$ infection among hemodialysis patients from Central Anatolia. J Pure Appl Microbiol 2014:8:435-40.

6. Aygen B, Deniz K, Akhan S, Çelen MK, Yıldız O, Ayaz C, et al. Frequency and epidemiologic characteristics of hepatitis $\mathrm{C}$ virus infection in patients receiving hemodialysis in our region. Klimik Journal 2012;25:19-23. [CrossRef]

7. Gökahmetoğlu S, Bozdayı M, Özbakır Ö, Aygen B, Özbal Y, Soyuer I, et al. Hepatitis C virus genotypes detected in Erciyes University. Journal of Turkish Society of Microbiology 2007;37:35-8.

8. Gökahmetoğlu S, Atalay MA, Kılınç A. Determination of the hepatitis C virus genotypes with "pyrosequencing" method. Erciyes Medical Journal 2011;33:99-102.

9. Fried MW, Shiffman ML, Reddy KR, Smith C, Marinos G, Gonçales FL Jr, et al. Peginterferon alfa-2a plus ribavirin for chronic hepatitis C virus infection. N Engl J Med 2002;347:975-82. [CrossRef]

10. Manns MP, McHutchison JG, Gordon SC, Rustgi VK, Shiffman $\mathrm{M}$, Reindollar R, et al. Peginterferon alfa-2b plus ribavirin compared with interferon alfa- $2 \mathrm{~b}$ plus ribavirin for initial treatment of chronic hepatitis C: a randomised trial. Lancet 2001;358:958-65. [CrossRef]

11. Kamal SM, Nasser IA. Hepatitis C genotype 4: what we know and what we don't yet know. Hepatology 2008;47:1371-83. [CrossRef]

12. McHutchison JG, Everson GT, Gordon SC, Jacobson IM, Sulkowski M, Kauffman R, et al. Telaprevir with peginterferon and ribavirin for chronic HCV genotype 1 infection. $N$ Engl $J$ Med 2009;360:1827-38. [CrossRef]

13. McHutchison JG, Manns MP, Muir AJ, Terrault NA, Jacobson IM, Afdhal NH, et al; PROVE3 Study Team. Telaprevir for previously treated chronic HCV infection. N Engl J Med 2010; 362:1292-303. [CrossRef]

14. Jacobson IM, McHutchison JG, Dusheiko G, Di Bisceglie AM, Reddy KR, Bzowej NH, et al; ADVANCE Study Team. Telaprevir for previously untreated chronic hepatitis $\mathrm{C}$ virus infection. N Engl J Med 2011;364:2405-16. [CrossRef]

15. Sherman KE, Flamm SL, Afdhal NH, Nelson DR, Sulkowski MS, Everson GT, et al; ILLUMINATE Study Team. Responseguided telaprevir combination treatment for hepatitis $\mathrm{C}$ virus infection. N Engl J Med 2011;365:1014-24. [CrossRef]

16. Zeuzem S, Andreone P, Pol S, Lawitz E, Diago M, Roberts S, et al; REALIZE Study Team. Telaprevir for retreatment of HCV infection. N Engl J Med 2011;364:2417-28. [CrossRef]

17. Benhamou Y, Moussalli J, Ratziu V, Lebray P, De Backer K, De Meyer S, et al. Telaprevir activity in treatment-naive patients infected hepatitis $\mathrm{C}$ virus genotype 4: a randomized trial. $J$ Infect Dis 2013;208:1000-7. [CrossRef]

18. Ishak K, Baptisa A, Bianchi L, Callea F, De Groote J, Gudat F, et al. Histological grading and staging of chronic hepatitis. $J$ Hepatol 1995;22:696-9. [CrossRef]

19. Omata M, Kanda T, Yu ML, Yokosuka O, Lim SG, Jafri W, et al. APASL consensus statements and management algorithms for hepatitis C virus infection. Hepatol Int 2012;6:409-35. [CrossRef]

20. Ghany MG, Strader DB, Thomas DL, Seeff LB; American Association for the Study of Liver Diseases. Diagnosis, management, and treatment of hepatitis C: an update. Hepatology 2009;49:1335-74. [CrossRef]

21. Sung H, Chang M, Saab S. Management of hepatitis C antiviral therapy adverse effects. Curr Hepat Rep 2011;10:33-40. [CrossRef]

22. European Association for the Study of the Liver. EASL Clinical Practice Guidelines: management of hepatitis $\mathrm{C}$ virus infection. J Hepatol 2011;55:245-64. [CrossRef]

23. El Awady MK, Bader El Din NG, Tabll A, El Hosary Y, Abdel Aziz AO, El Khayat H, et al. IL28B polymorphism and cytomegalovirus predict response to treatment in Egyptian HCV type 4 patients. World J Gastroenterol 2013;19:290-8. [CrossRef]

24. Muir AJ, Poordad FF, McHutchison JG, Shiffman ML, Berg T, Ferenci $\mathrm{P}$, et al. Retreatment with telaprevir combination therapy in hepatitis $\mathrm{C}$ patients with well-characterized prior treatment response. Hepatology 2011;54:1538-46. [CrossRef]

25. Poynard T, Colombo M, Bruix J, Schiff E, Terg R, Flamm S, et al. Peginterferon alfa-2b and ribavirin: effective in patients with hepatitis $\mathrm{C}$ who failed interferon alfa/ribavirin therapy. Gastroenterology 2009;136:1618-28. [CrossRef]

26. Shiffman ML, Di Bisceglie AM, Lindsay KL, Morishima C, Wright EC, Everson GT, et al; Hepatitis C Antiviral Long-Term Treatment Against Cirrhosis Trial Group. Peginterferon alfa-2a and ribavirin in patients with chronic hepatitis $\mathrm{C}$ who have failed prior treatment. Gastroenterology 2004;126:1015-23. [CrossRef]

27. Ghany MG, Nelson DR, Strader DB, Thomas DL, Seeff LB. An update on treatment of genotype 1 chronic hepatitis $C$ virus infection: 2011 practice guideline by the American Association for the Study of Liver Diseases. Hepatology 2011;54:1433-44. [CrossRef] 